\title{
Menerapkan Profil Daud Sebagai Pemimpin di Gereja Orthodox Evangelismos Pargambiran Sumbul, Dairi
}

\author{
Parluhutan Manalu \\ Sekolah Tinggi Teologi Paulus, Medan \\ parluhutan-m@gmail.com
}

\begin{abstract}
The purpose of this research is to create a leader who is humble and sincere in leading God's people and who is responsible for his people. A leader is very important in an organization, group or in a church so he is required to be truly responsible for leading or directing the people he leads, this can be done by understanding David's profile as a leader. After conducting research by asking 8 questions with 8 respondents, the cumulative percentage of $72.665 \%$ was obtained, which means that the church leaders in the Orthodox Church Evangelismos Pargambiran, Sumbul, Dairi implemented David's leadership well in leading and carrying out tasks that had entrusted by God to him. The author's hopes for the future can be emulated: David's profile as a leader so as to realize leaders who are truly humble and responsible in leading their people.
\end{abstract}

Keywords: David's profile; church leaders; leadership; Orthodox Evangelismos Church

\begin{abstract}
Abstrak: Tujuan dari penelitian ini adalah untuk mewujudkan pemimpin yang rendah hati dan dan tulus dalam memimpin umat Allah dan yang bertangung-jawab atas umatnya. Seorang pemimpin sangat penting dalam sebuah organisasi, kelompok ataupun dalam sebuah gereja sehingga dia dituntut untuk sungguh-sunguh bertanggung-jawab dalam memimpin atau mengarahkan orangorang yang dipimpinnya, hal ini dapat dilakukan dengan memahami profil Daud sebagai Pemimpin. Setelah dilakukan penelitian dengan mengajukan 8 buah pertanyaan dengan 8 orang responden diperoleh hasil akumulatif presentase sebesaar $72,65625 \%$ yang artinya bahwa pemimpin gereja yang ada di Gereja Orthodox Evangelismos Pargambiran, Sumbul, Dairi menerapkan dengan baik kepemimpinan Daud dalam memimpin dan dalam melaksanakan tugas yang telah dipercayakan oleh Allah kepadanya. Harapan penulis ke depan bisa diteladani: Profil Daud sebagai pemimpin sehingga dapat mewujudkan pemimpin-pemimpin yang benar-benar rendah hati dan bertanggungjawab dalam memimpim umatnya.
\end{abstract}

Kata kunci: Gereja Orthodox Evangelismos; kepemimpinan; profil Daud; pemimpin gereja

\section{PENDAHULUAN}

Kepemimpinan merupakan pokok penting dalam sebuah organisasi. Dimulai dari organisasi yang terkecil seperti dalam keluarga sampai kepada organisasi terbesar yaitu organisasi pemerintahan dan dunia. Apa yang dialami oleh manusia sekarang ini tidak lepas dari apa yang telah dilakukan oleh para pemimpin. Di tangan para pemimpinlah arah masa depan manusia berada karena biasanya visi datang dari pemimpin. Oleh sebab itu dapat digambarkan bahwa apabila para pemimpin tidak mempunyai visi atau arah yang jelas, maka masa depan rakyat pun akan hancur dan sebaliknya. Pemimpin itu menentukan hidup atau mati banyak orang. Jules Archer berkata: "Ketika Hitler berkuasa di Jerman, 
orang-orang Yahudi dn Rusia dianiaya secara besar-besaran, termasuk umat beragama. ${ }^{1}$ Ketika bangsa Israel dipimpin oleh raja yang takut akan Tuhan, maka rakyatnya hidup dalam damai, dan apabila pemimpinnya adalah pemimpin yang tidak takut akan Tuhan maka penderitaan yang dialami oleh rakyatnya.

Jika berbicara tentang kepemimpinan, secara sepintas terlintas dalam benak manusia adalah kekuasaan dan kekayaan. Kepemimpinan identik dengan kekuasaan dan kekayaan. Charles R. Swindoll mengatakan, "Menjadi seorang pemimpin adalah panggilan yang dapat menimbulkan keirian hati." ${ }^{2}$ Dalam Perjanjian Lama ditemukan model kepemimpinan yang mengikuti pola Allah. Istilah ini dikenal dengan "Theokrasi”, di mana Allah langsung menuntun, membimbing, melindungi dan menjamin kehidupan umat. Di dalam konteks Perjanjian Lama sangat jelas digambarkan bagaimana keberhasilan seorang pemimpin yang optimal dengan penyertaan Allah yang senantiasa menuntun kepemimpinannya. Penyimpangan Saul dengan melakukan yang jahat di mata Tuhan (1Sam. 15:19), menyebabkan Allah murka sehingga Ia mengganti Saul sebagai pemimpin seluruh bangsa Israel. Dengan demikian Allah melihat bahwa seorang pemimpin yang baik bukan lagi tergantung dari rupa dan penampilan melainkan dari hati yang tulus. Jhon C. Maxwel menuturkan: "Segala sesuatu, jatuh bangunnya tergantung pada pemimpin.",3

Ada beberapa model kepemimpinan Kristen seperti pada gaya kepemimpinan otoriter atau otokratis dimana pemimpin memerintah pengikutnya untuk mengerjakan tugas dan gaya ini hanya sedikit pendelegasian wewenang serta pemimpin tidak memberikan penjelasan tentang apa yang harus dilakukan. Gaya demokratis atau partisipatif dimana pemimpin mendorong pengikutnya untuk berpartisipasi dalam kegiatan-kegiatan kelompok dan pengambilan keputusan, dan dalam kepemimpinan ini terjalinlah hubungan yang dekat antar anggota kelompok. Gaya paternalistik yaitu dimana pemimpin model ini mengarah kepada adat istiadat setempat misalnya menghormati orang tua yang dituakan karena dianggap lebih berpengalaman dan berhikmat.

John MacAtur mengatakan, pemimpin adalah seorang yang memiliki hidup dan karakter yang dapat mendorong orang lain untuk meneladaninya. ${ }^{4}$ Artinya, kepemimpinan erat sekali kaitannya dengan memberikan teladan, dan hal tersebut harus dipraktikkan dari sejak dini. ${ }^{5}$ Sementara, J. Oswald Sanders menekankan kepemimpinan pada hal memberi pengaruh. Dan, menurut Lord Montogomeri, "Kepemimpinan adalah kemampuan dan kehendak untuk menggerakkan orang laki-laki dan perempuan untuk satu tujuan bersama dan watak yang menimbulkan kepercayaan." Jonathan Willy S, mengatakan kepemimpinan adalah seseorang atau sekelompok yang memimpin dan mengarahkan kelompoknya

\footnotetext{
${ }^{1}$ Jules Archer, Kisah Para Diktator, (Jakarta: Narasi, 2004), 146-147.

${ }^{2}$ Charles R. Swindoll, Kepemimpinan Kristen Yang Berhasil, (Surabaya: Yakin, 2003), 6. 1993), 8 .

${ }^{3}$ Jhon C. Maxwel, Mengembangkan Kepemimpinan di Dalam Diri Anda, (Georgia: Equip, Injoy, Inc,

${ }^{4}$ John MacAtur, Kitab Kepemimpinan, (Jakarta: Erlangga, 1983), 123.

${ }^{5}$ Desti Samarenna and Harls Evan R Siahaan, "Memahami Dan Menerapkan Prinsip Kepemimpinan Orang Muda Menurut 1 Timotius 4:12 Bagi Mahasiswa Teologi," BIA': Jurnal Teologi dan Pendidikan Kristen Kontekstual 2, no. 1 (2019): 1-13, http://www.jurnalbia.com/index.php/bia.

${ }^{6}$ Ibid., 20.
} 
menuju suatu tujuan secara bersama. ${ }^{7}$ Soejono Iamy menekankan kepemimpinan sebagai sebuah proses saat seseorang mempengaruhi orang lain dalam hal keyakinan, tingkah laku dan kebiasaan, agar sesuai dengan apa yang dibutuhkan, dan sesuai dengan norma dan keyakinan organisasinya. ${ }^{8}$

Dalam perspektif Allkitab, khususnya Perjanjian Lama, Sanders mengatakn, bahwa ketika Allah benar-benar menemukan seseorang yang sesuai dengan tuntutan kerohanianNya, yang rela memenuhi segala tuntutan kepemimpinan, Ia memakainya tanpa memedulikan segala kelemahan dan keterbatasannya yang nyata. ${ }^{9}$ Tugas kepemimpinan adalah untuk menetapkan langkah-langkah yang harus dikerjakan atau melihat dan menjangkau visi dan misi perjalanan kepemimpinan itu. Menurut Kenneth dan Linda Schatz, bahwa tugas pe-mimpin adalah memberi dukungan dan menggerakkan anggota. Para anggota perlu diberi-kan dorongan semangat dengan meyakini, bahwa mereka memiliki kemandirian dan sumber daya yang diperlukan demi keberhasilan pelaksanaan tanggung jawab mereka. ${ }^{10}$

Yacob Tomatala mengatakan bahwa: "Kepemimpinan memegang peranan penting, kepemimpinan menentukan maju mundurnya suatu organisasi." 11 Dari pernyataan ini terbukti bahwa kepemimpinan mempengaruhi kehidupan organisasi manapun didunia. Mengevaluasi pemimpin harus memeriksa apakah idea atau rencana berjalan sesuai rencana atau tidak. Hal-hal yang perlu dievaluasi adalah kinerja kelompok, individu, bahkan kinerja kepemimpinannya sendiri. ${ }^{12}$ Jadi bila dilihat dari pentingnya sebuah kepemimpinan dalam gereja agar terdapat pemimpin-pemimpin yang ideal dalam memimpin sebuah oraganisasi atau dalam memimpin suatu kelompok, baik dalam bidang kerohanian maupun dalam bidang jasmani, dapat terjadi suatu perubahan sehingga setiap pemimpin gereja pada masa sekarang ini dapat memimpin suatu organisasi atau dapat mengarahkan jemaatnya ke arah yang lebih baik.

Menurut Fredsmith ada beberapa hal kriteria seorang pemimpin yang baik, yaitu: Kehidupan rohani, yaitu orang-orang yang ingin menjadi pemimpin harus memiliki karakter yang baik dalam kehidupan rohaninya; Kehidupan pribadi, yaitu apa yang dilakukan pemimpin saat ia tidak berada di atas mimbar akan menentukan apa yang harus muncul di mimbar. Apa yang terjadi dalam kehidupan berpengaruh pada apa yang terjadi di depan umum. Menjadi pemimpin harus menjaga kehidupan rohaninya dengan baik; Kehidupan sosial, ia harus memiliki karakter yang baik dalam kehidupan sosialnya. Kehidupan pernikahan dan keluarga, syarat untuk menjadi pemimpin harus memiliki karakter yang baik dalam pernikahan dan keluarganya; Kehidupan keuangan, harus memiliki karakter yang baik dengan keuangan. Mereka yang berada dalam kepemimpinan rohani harus mampu

\footnotetext{
${ }^{7}$ Ibid., 8.

${ }^{8}$ Soejono Iamy, Analisis Kepemimpinan (Bandung: Angkasa, 1989), 1.

${ }^{9}$ J. Oswald Sanders, Spiritual Leadership (Chicago: Moody, 1967), 16.

${ }^{10}$ Kenneth dan Linda Schatz, Keberhasilan Daya Dalam Pengaruh Manajemen (Jakarta: Spectrum Mitra Utama, 1995), 9.

${ }^{11}$ Yacob Tomatala, Kepemimpinan Yang Dinamis (Jakarta: YT Leadership Foundation, 1997), 5.

${ }^{12}$ Jonathan Willy S, Lead By Heart (Yogyakarta: Andi Offset, 2009), 8-9.
} 
mengelola uang yang ada dengan baik. Mereka tidak boleh berhutang; Perkataan, ia harus memiliki karakter dalam perkataannya. Ia harus mengatakan kebenaran, ini adalah satu wilayah yang sangat penting; Integritas, Fredsmith mengatakan bahwa, "pengharapan terhadap diri sendiri adalah indikator penting dalam integritas kita sebagai manusia atau seorang pemimpin. ${ }^{13}$

\section{Profil Daud Sebagai Pemimpin: Kunci Sukses}

\section{Dipilih oleh Allah}

Kata "pemilihan" dalam Perjanjian Lama artinya tindakan Allah dalam memilih seseorang atau suatu kelompok dari dalam suatu persekutuan yangg lebih besar, untuk tujuan atau masa depan yg ditentukan-Nya sendiri. Dalam bahasa Ibrani kata "pemilihan" adalah " (bakhar), yang berarti memilih seseorang atau sesuatu dengan seksama, sesudah menimbang dengan masak-masak kemungkinan-kemungkinan lain (mis. batu umban, 1Sam. 17:40; tempat perlindungan, Ul. 23:16; istri, Kej. 6:2; yang baik bukan yang jahat, Yes. 7: I5 dab; hidup bukan mati, Ul. 30:19). ${ }^{14}$ Dalam Perjanjian Baru kata pemilihan adalah

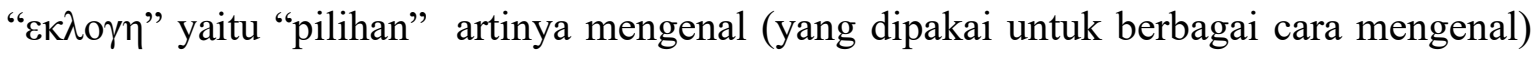
misalnya Yesus dinyatakan sebagai yang dipilih Allah Bapa sendiri (Luk. 9:35) Yesus sendiri menjadi yang sulung dari semua orang pilihan Allah, Allah menyatakan tentang Yesus: "Lihatlah, itu hamba-Ku yang Kupilih" (Mat 12:18; Yes 42:1,6; 1Pet 2:4). ${ }^{15}$

Daud memiliki karakter yang mencolok. Dia penggubah lagu-lagu yang paling disukai oleh bangsa Israel dalam Mazmur. Daud menjadi raja atas pilihan Allah sendiri atau Allah sendiri. Allah memilihnya karena dia adalah seorang yang tulus hati dalam mengerjakan pekerjaan atau dalam melaksanakan tugas yang telah diberikan kepadanya (1Sam. 16:1-13). Allah memilih Daud sebagai raja atau pemimpin bagi bangsa Israel bukan karena parasnya yang elok karena bukan tampangnya yang dilihat Allah kepada seorang pemimpin. Artinya, untuk menjadi seorang pemimpin bukan fisiknya yang bagus dan materi atau kekayaannya yang dilihat tetapi Allah sendiri yang mengatakan bahwa yang dilihat kepada seorang pemimpin adalah hatinya. Allah memilih Daud sebagai raja atau menjadi pemimpin kepada bangsa Israel bukan karena ketampanannya (ia kemerahmerahan, matanya indah dan parasnya elok), tetapi karena Allah melihat Daud seorang manusia biasa yang memiliki keberanian. Sehingga, pada akhirnya Tuhan berfirman kepada Samuel untuk mengurapi Daud sebagai raja atau sebagai pemimpin bangsa Israel.

Ada beberapa hal alasan mengapa Daud dipilih sebagai raja atau sebagai pemimpin oleh Allah. Pertama, karena Daud memiliki jiwa seni, ia seorang pemain kecapi bagi Saul. Dalam tradisi kuno Daud adalah seorang pemazmur yang disenangi oleh Israel (2 Sam. 13:1) dan tulisan Perjanjian Lama yang kemudian menyebut peranannya memimpin ibadah musik Israel, membuat alat-alat musik dan (Neh. 12:24, 36, 45-46). Keahlian Daud dalam bermain kecapi terbukti pada saat ia mengusir roh jahat kepada Saul (1Sam. 16:16-17). Dari keahlian Daud bermain kecapi nama Tuhan telah dimuliakan oleh Saul.

\footnotetext{
${ }^{13}$ Fredsmith. SR, Pemimpin Dengan Integritas, (Jakarta: Immanuel, 2002), 17.

${ }^{14}$ http://Alkitab.sabda.Pilih, Pemilihan, Diakses: 06-03-2020

${ }^{15}$ http://Alkitab.sabda. Pilih, Pemilihan, Diakses: 06-03-2020
} 
Kedua, Daud memiliki jiwa patriotis. Daud adalah seorang pahlawan yang gagah perkasa dan juga seba-gai seorang prajurit (1Sam. 16:18). Jika dilihat dari fisik maka Daud bukan bandingan Goliat, karena badan Goliat lebih perkasa daripada Daud. Namun dalam hal ini karena Daud adalah seorang pahlawan yang mengandalkan Tuhan. Daud dikatakan layak sebagai pahlawan karena adanya pengakuan dari rakyat yang dipimpinnya. Wibawa yang ada padanya bukan berasal dari dirinya sendiri, melainkan karena Tuhan campur tangan dalam proses pemilihannya. Jika Tuhan yang memilih, maka kepemimpi-nannya selalu mengemban tugas penggembalaan. Hal ini sejalan dengan konsep raja di Israel yang menjalankan peran sebagai gembala, bukan hanya sebagai pemimpin politik. Selain itu, Daud adalah seorang yang memiliki perencanaan matang dalam setiap tindakan. Setelah diurapi menjadi raja oleh tua-tua Israel, kemampuan Daud dalam memimpin diuji dengan merebut kota Yerusalem. Dan yang tidak kalah penting adalah adanya pengakuan dari negara lain. Hiram, raja Tirus juga menaruh hormat kepada dia. Kepemimpinan Daud nyata dalam tindakannya sampai pada adanya pengakuan dari negara tetangga.

Ketiga, Daud adalah seorang pemimpin atau raja yang sangat pandai untuk bebicara (1Sam. 16:18). Modal dari keberanian Daud untuk melawan musuh-musuhnya adalah pandai berbicara. Keempat, Daud adalah seorang yang yang miskin dan renndah hati. Kerendahan hati Daud dapat dilihat ketika ia sedang mengembalakan domba-domba ayahnya, ia tidak bersungut-sungut. Walaupun hanya dia yang mengejakannya namun dia tetap serius dan dengan hati yang tulus mengerjakan tugas-tugasnya (1Sam. 18:23). Kelima, penyertaan Allah pada kepemimpinan Daud telah terbukti pada saat Daud melawan musuh-musuhnya, dan terkhusus waktu dia melawan Goliat (1Sam. 17:40-50). Daud mengalahkan Goliat bukan dengan pedang, tetapi hanya dengan umban dan batu. Demikian juga pada saat Saul mengejar-ngejar Daud, Allah tetap melindungi dia dan tidak mem-biarkan Daud dibunuh oleh Saul. Saul sangat membenci Daud karena keberhasilannya da-lam memimpin bangsa Israel, tetapi Allah tetap menyertai dia sehingga seluruh bangsa Israel dan Yehuda mengasihi dia (1Sam. 18:16).

\section{Diurapi oleh Allah}

Pengurapan berasal bahasa Yunani yaitu "É $\chi \rho ı \varepsilon$ ” yang artinya diurapi mengurapi. Dalam bahasa Ibrani berasal dari kata "mâsyakh" yang artinya mengurapi, melumuri, mengolesi sesuatu dengan minyak. Pengurapan berasal dari kata dalam bahasa Inggris, yaitu: "to anoint" artinya mengurapi. ${ }^{16}$ Dalam Perjanjian Lama, ada tiga jabatan publik yang harus diurapi, antara lain: Nabi (1Raj. 19:16), Imam (Kel. 28:41), Raja (2Sam. 2:4), dalam pengertian ditahbiskan sebagai alat khusus bagi Allah.

Dalam Perjanjian Baru, yang diurapi mengacu kepada Yesus Kristus artinya yang diurapi, (Kis. 10:38), minyak urapan merupakan simbol dari Roh Kudus. Demikian juga orang yang percaya kepada Kristus juga menerima pengurapan (1Yoh 2:20). Pengertian pengurapan disini jelas sekali sebagai yang menerima Roh Kudus, lahir baru, percaya. Artinya, ketika kita menjadi percaya, urapan Roh Kudus ada pada kita. Jadi arti dari peng-

\footnotetext{
${ }^{16}$ http://www. Pengurapan Secara Alkitab, Diakses: 06-03-2020
} 
urapan adalah untuk menyatakan bahwa Roh Allah telah turun dan menyertai orang yang diurapi, sebagaimana minyak juga adalah salah satu simbol dari Roh Allah. ${ }^{17}$ Daud diurapi dengan minyak oleh Samuel untuk menjadi raja (1Sam. 16:12). Allah menghendaki Daud dan mengurapi dia menjadi raja bagi bangsa Israel karena beberapa hal:

Pertama, Daud adalah seorang yang dipilih oleh Tuhan sebagai orang yang berkenan dihati-Nya (1Sam. 13:14). Rasul Lukas mencatat bahwa: "Setalah Saul disingkirkan, Allah mengangkat Daud menjadi raja mereka (bangsa Israel). Tentang Daud Allah telah menyatakan: Aku telah mendapatkan Daud bin Isai, seorang yang berkenan di hati-Ku dan yang melakukan segala kehendak-Ku (Kis.13:22). Allah mengatakan Daud adalah orang berkenan dihati-Nya karena kesetiaannya. Dengan kesetiaan Daud menjaga kambing dombanya, Allah menilai Daud bahwa untuk menjaga kambing domba yang dua tiga ekor Daud setia dan sepenuh hati menjaga maka untuk memimpin bangsa Israel ia pimpin dengan sepenuh hati juga (Luk. 16:10).

Kedua, Daud selalu ingin menyenangkan hati Allah. Walaupun Daud hidup di istana yang megah dan indah namun hati Daud gundah gulana sebab Tuhan yang ia sembah hanya tinggal di sebuah kemah. Banyak orang Kristen yang apabila sudah hidup enak dan berhasil melupakan Tuhan, tapi Daud tidak sebab hati Daud adalah hati yang ingin menyenangkan Tuhan. Daud mencintai Tuhan Allah dengan segenap hati, jiwa dan pikirannya. Bagi Daud, Tuhan merupakan kekasih dan pujaan hatinya. Bila Tuhan senang maka Daud senang, bila Tuhan tidak senang maka Daud tidak senang juga.

Ketiga, Daud memiliki sikap yang taat. Selama bertahun-tahun Daud dikejar-kejar dan ingin dibunuh oleh Saul sebab ia iri hati terhadap Daud. Beberapa kali Daud mempunyai kesempatan untuk membunuh Saul namun ia tidak melakukannya sebab ia tidak ingin menjamah orang yang diurapi oleh Tuhan. Daud menyadari bahwa melawan otoritas berarti melawan si pemberi otoritas. Daud menunggu dengan sabar sampai Tuhan sendiri yang mengambil otoritas dari diri Saul.

Keempat, Daud memiliki hati yang mengampuni. Daud mengampuni Saul walaupun Saul mengejar-ngejar dan ingin membunuhnya. Bahkan Daud bersedih dan meratap ketika mendengar Saul telah meninggal. Daud juga mengampuni Absalom, anaknya sendiri yang telah menghianatinya dan ingin menjadi raja. Daud juga memiliki hati yang lemah-lembut. Meskipun dalam kelemahannya Daud sempat melakukan dosa perzinahan dan pembunuhan namun ia cepat bertobat saat Tuhan menegurnya lewat nabi Natan. Inilah yang membedakan antara Saul dengan Daud dimana ketika Saul ditegur oleh Samuel ketika Saul berbuat salah ia tidak mau bertobat. Sebagai manusia biasa kita tidak mungkin dapat luput dari kesalahan tetapi kita harus cepat bertobat dan berubah bila ditegur oleh Tuhan.

\section{Daud Sebagai Pemimpin}

Allah memilih Daud sebagai raja atau pemimpin karena sudut pandangnya yang unik. Daud melihat segala sesuatunya dari kacamata Allahnya yang besar. Allah yang memungkinkan segala sesuatu, Allah yang membuat yang tidak ada menjadi ada, Allah yang adil,

\footnotetext{
${ }^{17}$ http://www. Pengurapan Secara Alkitab, Diakses: 06-03-2020
} 
Allah yang benar, Allah yang setia dengan janjinya, Allah yang mencintai manusia dan Allah yang memilih bangsa Israel untuk menjadi umat pilihan-Nya. Dasar inilah yang dipegang teguh oleh Daud di setiap kehidupannya.

Dalam diri Daud terpadu dengan baik sekali keberanian pribadi dengan keterampilan sebagai panglima dan dengan bakat ini ia memimpin bangsa Israel menundukkan musuhmusuhnya secara teratur yaitu orang Filistin, Kanaan, Moab, Arnon, Aram, Edom dan Amalek sehingga namanya tertulis dalam sejarah, sama sekali lepas dari arti pribadinya dalam rencana pelepasan Allah (1Sam. 27-30). ${ }^{18}$ Maka segera kelihatan bukti dari kegairahan Daud dalam soal keagamaan. Dibawanya tabut perjanjian dari Kiryat-Yearim dan di tempatkan dalam Kemah Suci yang dibangun khusus untuk itu di Yerusalem. Banyak dari peraturan keagamaan yang memperkaya kebaktian Bait Suci di kemudian hari, bermula pada susunan kebaktian dalam Kemah Suci, yang dibuat oleh Daud pada waktu ini. ${ }^{19}$

Kepemimpinan Daud telah diakui oleh umat Israel sejak Saul menjadi raja. Namun wibawa yang ada padanya bukan berasal dari dirinya sendiri, melainkan karena Tuhan campur tangan dalam proses pemilihannya. Jika Tuhan yang memilih, maka kepemimpinannya selalu mengemban tugas penggembalaan. Daud juga memiliki perencanaan matang dalam setiap tindakan. Setelah diurapi menjadi raja oleh tua-tua Israel, kemampuan Daud dalam memimpin diuji dengan merebut kota Yerusalem. Orang-orang Yebus, penduduk kota itu, ternyata meremehkan dia. Namun Daud berhasil merebut kubu pertahanan Yerusalem, yakni Sion. ${ }^{20}$

Dari hal tersebut di atas, maka kepemimpinan yang sangat cocok untuk diterapkan di gereja adalah Daud. Daud dipilih dan diurapi menjadi raja karena Allah melihat hati Daud penuh dengan ketulusan dan ketaatan dan kerendahan hati dalam menuntun bangsanya. Tujuan yang ingin dicapai dalam penelitian ini adalah untuk memperlihatkan profil Daud sebagai pemimpin, yang dapat diterapkan dalam kepemimpinan di gereja Orthodox Evangelismos Pargambiran Sumbul, Dairi.

\section{METODE PENELITIAN}

Metode yang digunakan dalam penelitian ini adalah deskriptif dengan pendekatan kualitatif literatur atau penelitian berdasarkan analisis literatur kepustakan. Husein Umar mengatakan "Metode deskriptif bertujuan untuk menggambarkan sifat sesuatu yang tengah berlangsung pada saat penelitian dilakukan dan memiliki sebab-sebab dari sesuatu gejala tertentu. ${ }^{21}$ Tempat penelitian penulis adalah Gereja Orthodox Evangelismos Pargambiran Sumbul, Dairi, Sumatra Utara. Subyek dalam penelitian ini adalah: 1 orang dari bagian Pelayan Jemaat (Voorhanger), 2 orang dari Komisi Kaum Perempuan, 2 orang dari Komisi Kaum Bapa, 2 orang dari Komisi Pelayan Anak, 1 orang dari Komisi Kaum Muda/i.

\footnotetext{
${ }^{18} \mathrm{http}: / /$ www. Kepemimpinan Daud, Diakses: 06-03-2020.

${ }^{19} \mathrm{http} / / /$ www. Kepemimpinan Daud, Diakses: 06-03-2020

${ }^{20}$ http://www. Persekutuan Pembaca Alkitab.or.id. Diakses: 06-03-2020

${ }^{21}$ Husein Umar, Metode Penelitian Untuk Tesis, (Jakarta: PT. Raja Grafindo Persada, 2004), hlm. 22.
} 


\section{Teknik Analisis Data}

Dalam analisis data ini akan dilakukan penyajian data yang diperoleh dari lapangan sebagai hasil pengamatan serta melalui pengamatan penulis dan hasil wawancara dengan responden dan gembala sidang, maka ini disebut dengan triangulasi. Triangulasi data dilakukan melalui pengamatan peneliti dan hasil wawancara. Dan untuk mengukur hasil wawancara, penulis menggunakan sistem persentase, adapun rumus yang digunakan adalah:

$$
\begin{aligned}
& P=\frac{F}{N} \times 100 \% \\
& \mathrm{P}=\frac{\text { Jumlah Frekuensi Tiap Jawaban }}{\text { Jumlah Sampel }} \times 100 \% \\
& \mathrm{AP}=\frac{\mathrm{FA} \times 4+\mathrm{FB} \times 3+\mathrm{FC} \times 2+\mathrm{FD} \times 1}{\mathrm{SI}(\text { Skor Ideal })} \times 100 \% \\
& \text { Keterangan: } \\
& \mathrm{F} \quad=\text { Frekuensi } \\
& \mathrm{N}=\text { Jumlah Sampel Penelitian } \\
& \mathrm{P} \quad=\text { Presentase } \\
& \mathrm{AP} \quad=\text { Akumulatif Presentase } \\
& \text { SI }=\text { Skor Ideal (Skor Tertinggi } \mathrm{x} \text { N) } \\
& \text { Skor } \mathrm{A}=4 \\
& \text { Skor } \mathrm{B}=3 \\
& \text { Skor } \mathrm{C}=2 \\
& \text { Skor } \mathrm{D}=1^{22}
\end{aligned}
$$

Untuk jumlah rata-rata akumulatif presentase variabel $\mathrm{X}$ dan $\mathrm{Y}$, maka rumus yang digunakan ialah:

$$
\mathrm{AP} \%=\frac{\sum \%}{\text { Jumlah Item }}
$$

Di mana: $\mathrm{AP} \%=$ rata-rata persentase, dan $\sum \%=$ jumlah keseluruhan persentase. Untuk melihat presentase bagaimana pemahaman Gereja Orthodox Evangelismos Pargambiran tentang profil Daud sebagai pemimpin digunakan kriteria dan pengkategorian sebagai berikut:
a. $75 \%-100 \%$ : Sangat Menerapkan.
b. $50 \%-74 \%$ : Menerapkan.
c. $25 \%-49 \%$ : Kurang Menerapkan.
d. $0 \%-24 \%$ : $\quad$ Tidak Menerapkan ${ }^{23}$

${ }^{22}$ Etiknius Harefa, Diktat Metode Penelitian Theologia (Medan: STT Paulus, 2011), 24-31

${ }^{23}$ Nana Sudjana, Penelitian dan Penilaian Pendidikan (Jakarta: Sinar Baru Algensindo, 2001), 96. 


\section{HASIL DAN PEMBAHASAN}

\section{Deskriptif Data Penelitian}

Hal yang diteliti adalah: Profil Daud sebagai pemimpin dan aplikasinya bagi Pemimpin Gereja Orthodox Evangelismos Pargambiran Sumbul. Wawancara secara terstruktur yang diberikan kepada warga jemaat Gereja Orthodox Pargambiran Sumbul bertujuan agar pemimpin mampu mengaktualisasikan Profil Daud sebagai pemimpin dalam memimpin keseharian jemaat mereka.

\section{Profil Daud Sebagai Pemimpin}

Profil Daud sebagai pemimpin yang memimpin dengan hati yang tulus tanpa mementingkan dirinya sendiri, dan seluruh kepemimpinannya didasarkan atas kekuatan Tuhan pada dirinya.

1. Daud dipilih langsung oleh Allah, karena:
a. Daud memiliki jiwa seni.
b. Daud adalah seorang pahlawan.
c. Daud adalah seorang yang pandai berbicara.
d. Daud adalah seorang pemimpin yang rendah hati.
e. Daud adalah seorang yang baik hati.
f. Daud adalah seorang pemimpin yang disertai oleh Allah.

2. Daud diurapi oleh Allah, karena:
a. Daud adalah seorang yang berkenan dihati Allah.
b. Daud adalah selalu menyenangkan hati Allah.
c. Daud adalah orang yang taat akan perintah Allah.
d. Daud adalah seorang yang memiliki hati yang mau mengampuni.
e. Daud adalah seorang yang memiliki hati yang lemah-lembut.

Dari hal tersebut di atas perlu diketahui bahwa seorang pemimpin itu bukan hanya sekadar memdapatkan gelar atau sekedar nama sebagai pemimpin, tetapi orang yang benarbenar dipilih dan diurapi oleh Allah dan juga orang yang memiliki kemampuan untuk memimpin. Seorang pemimpin juga harus memiliki talenta yang luar biasa dan bertanggungjawab atas tugas dan pekerjaan yang telah dipercayakan pada dirinya, sehingga kepemimpinannya dapat keberhasilan dan nama Tuhan yang dimuliakan.

\section{Interview}

Interview merupakan sumber data penulis yang kedua. Dalam hal ini, penulis melakukan wawancara dengan memberikan pertanyaan kepada responden secara langsung kepada sebagian warga Gereja Orthodox Evangelismos yaitu sebanyak 8 orang, dengan menggunakan wawancara terstruktur. Penulis memberikan pertanyaan sebanyak 8 soal dengan memakai aspek pemimpin dan kepemimpinan. Adapun deskripsi hasil data dari responden tersebut dengan persentase sebagai berikut: 


\section{Soal No. 1}

Dalam kepemimpinan selalu ada yang namanya komunikasi yang baik. Apakah di dalam Jemaat Anda sudah menerapkan komunikasi yang baik antara pemimpin dan anggotanya?

\begin{tabular}{|c|c|c|c|c|c|}
\hline No. & Option & $\begin{array}{l}\text { Frekuensi } \\
\text { (F) }\end{array}$ & $\begin{array}{l}\text { Hasil } \\
\text { persentase } \\
\text { (P) }\end{array}$ & $\begin{array}{l}\text { Hasil } \\
\text { akumulati } \\
\text { f } \\
\text { Persentase } \\
\text { (AP) }\end{array}$ & Keterangan \\
\hline $\begin{array}{l}1 \\
2 \\
3 \\
4\end{array}$ & $\begin{array}{l}\text { A } \\
\text { B } \\
\text { C } \\
\text { D }\end{array}$ & $\begin{array}{l}2 \\
5 \\
1 \\
0\end{array}$ & $\begin{array}{l}25 \% \\
62,5 \% \\
12,5 \% \\
0 \%\end{array}$ & $78,125 \%$ & $\begin{array}{l}\text { Dari data ini dapat dilihat bahwa } \\
\text { respon sumber data akan } \\
\text { kepemimpinan terha-dap } \\
\text { komunikasi yang baik adalah sangat } \\
\text { menerapkan. }\end{array}$ \\
\hline
\end{tabular}

\section{Soal No. 2}

Daud dalam kepemimpinannya selalu berusaha melakukan yang terbaik di hadapan Tuhan dan juga bangsa yang dipimpinnya. Bagaimana dengan pemimpin di Jemaat Anda, sudahkah menerapkan hal yang demikian?

\begin{tabular}{|l|l|l|l|l|l|}
\hline No. & Option & $\begin{array}{l}\text { Frekuensi } \\
(\mathrm{F})\end{array}$ & $\begin{array}{l}\text { Hasil } \\
\text { persentase } \\
\text { (P) }\end{array}$ & $\begin{array}{l}\text { Hasil } \\
\text { akumulatif } \\
\text { Persentase } \\
\text { (AP) }\end{array}$ & Keterangan \\
\hline 1 & A & 1 & $\begin{array}{l}12,5 \% \\
50 \%\end{array}$ & $68,75 \%$ & $\begin{array}{l}\text { Dari data ini dapat dilihat bahwa } \\
\text { respon sumber data akan pemimpin } \\
\text { yang selalu berusaha melakukan } \\
\text { yang terbaik dihadapan Tuhan } \\
\text { adalah menerap-kan. }\end{array}$ \\
\hline 4 & B & 4 & $37,5 \%$ & & \\
\hline
\end{tabular}

\section{Soal No. 3}

Bagaimana respon sumber data akan pemimpin yang mampu menyadari siapa dirinya di hadapan Tuhan?

\begin{tabular}{|l|l|l|l|l|l|}
\hline No. & Option & $\begin{array}{l}\text { Frekuensi } \\
(\mathrm{F})\end{array}$ & $\begin{array}{l}\text { Hasil } \\
\text { persentase } \\
(\mathrm{P})\end{array}$ & $\begin{array}{l}\text { Hasil } \\
\text { akumulatif } \\
\text { Persentase } \\
\text { (AP) }\end{array}$ & Keterangan \\
\hline 1 & A & 1 & $\begin{array}{l}12,5 \% \\
75 \%\end{array}$ & $75 \%$ & $\begin{array}{l}\text { Dari data ini dapat dilihat bahwa } \\
\text { respon sumber data akan pemimpin } \\
\text { yang mampu menyadari siap } \\
\text { dirinya dihadapan Tuhan adalah } \\
\text { sangat menerapkan. }\end{array}$ \\
\hline
\end{tabular}

\section{Soal No. 4}

Bagaimana respon sumber data akan seorang pemimpin yang rendah hati dan pemberani?

\begin{tabular}{|c|c|c|c|c|c|}
\hline No. & Option & $\begin{array}{l}\text { Frekuensi } \\
\text { (F) }\end{array}$ & $\begin{array}{l}\text { Hasil } \\
\text { persentase } \\
(\mathrm{P})\end{array}$ & $\begin{array}{l}\text { Hasil } \\
\text { akumulatif } \\
\text { Persentase } \\
\text { (AP) }\end{array}$ & Keterangan \\
\hline $\begin{array}{l}1 \\
2 \\
3 \\
4\end{array}$ & $\begin{array}{l}\text { A } \\
B \\
\text { C } \\
\text { D }\end{array}$ & $\begin{array}{l}2 \\
3 \\
3 \\
0\end{array}$ & $\begin{array}{l}25 \% \\
37,5 \% \\
37,5 \% \\
0 \%\end{array}$ & $71,875 \%$ & $\begin{array}{l}\text { Dari data ini dapat dilihat bahwa } \\
\text { respon sumber data akan seorang } \\
\text { pemimpin yang rendah hati dan } \\
\text { pemberani adalah menerapkan. }\end{array}$ \\
\hline
\end{tabular}




\section{Soal No. 5}

Bagaimana respon sumber data akan pemimpin yang memiliki hikmat yang berasal dari Allah?

\begin{tabular}{|l|l|l|l|l|l|}
\hline No. & Option & $\begin{array}{l}\text { Frekuensi } \\
(\mathrm{F})\end{array}$ & $\begin{array}{l}\text { Hasil } \\
\text { persentase } \\
(\mathrm{P})\end{array}$ & $\begin{array}{l}\text { Hasil } \\
\text { akumulatif } \\
\text { Persentase } \\
\text { (AP) }\end{array}$ & Keterangan \\
\hline 1 & A & 1 & $\begin{array}{l}12,5 \% \\
50 \%\end{array}$ & $68,75 \%$ & $\begin{array}{l}\text { Dari data ini dapat dilihat bahwa } \\
\text { respon sumber data aka pemimpin } \\
\text { yang memiliki hikmat yang berasal } \\
\text { dari Allah adalah menerapkan. }\end{array}$ \\
\hline 3 & B & 4 & $37,5 \%$ & & \\
4 & D & 3 & 0 & $0 \%$ &
\end{tabular}

\section{Soal No. 6}

Bagaimana respon sumber data akan pemimpin yang mengandalkan Tuhan dalam segala hal?

\begin{tabular}{|c|c|c|c|c|c|}
\hline No. & Option & $\begin{array}{l}\text { Frekuensi } \\
\text { (F) }\end{array}$ & $\begin{array}{l}\text { Hasil } \\
\text { persentase } \\
(\mathrm{P})\end{array}$ & $\begin{array}{l}\text { Hasil } \\
\text { akumulatif } \\
\text { Persentase } \\
\text { (AP) }\end{array}$ & Keterangan \\
\hline $\begin{array}{l}1 \\
2 \\
3 \\
4\end{array}$ & $\begin{array}{l}\text { A } \\
\text { B } \\
\text { C } \\
\text { D }\end{array}$ & $\begin{array}{l}1 \\
5 \\
2 \\
0\end{array}$ & $\begin{array}{l}12,5 \% \\
62,5 \% \\
25 \% \\
0 \%\end{array}$ & $71,875 \%$ & $\begin{array}{l}\text { Dari data ini dapat dilihat bahwa } \\
\text { respon data akan pemimpin yang } \\
\text { mmengandalkan Tuhan dalam } \\
\text { segala hal adalah menerapkan. }\end{array}$ \\
\hline
\end{tabular}

\section{Soal No. 7}

Bagaimana respon sumber data akan pemimpin yang kuat dan mampu menempatkan diri sebagai pemimpin dalam kepemimpinannya?

\begin{tabular}{|c|c|c|c|c|c|}
\hline No. & Option & $\begin{array}{l}\text { Frekuensi } \\
\text { (F) }\end{array}$ & $\begin{array}{l}\text { Hasil } \\
\text { persentase } \\
(\mathrm{P})\end{array}$ & $\begin{array}{l}\text { Hasil } \\
\text { akumulatif } \\
\text { Persentase } \\
\text { (AP) }\end{array}$ & Keterangan \\
\hline $\begin{array}{l}1 \\
2 \\
3 \\
4\end{array}$ & $\begin{array}{l}\text { A } \\
B \\
C \\
D\end{array}$ & $\begin{array}{l}1 \\
5 \\
2 \\
0\end{array}$ & $\begin{array}{l}12,5 \% \\
62,5 \% \\
25 \% \\
0 \%\end{array}$ & $71,875 \%$ & $\begin{array}{l}\text { Dari data ini dapat dilihat } \\
\text { bahwa respon sumber data } \\
\text { akan pemimpin yang kuat } \\
\text { dan mampu menempat-kan } \\
\text { diri sebagai pemimpin } \\
\text { adalah menerapkan. }\end{array}$ \\
\hline
\end{tabular}

\section{Soal No. 8}

Bagaimana respon sumber data akan pemimpin yang mampu menerima setiap pribadi orang yang dipimpinnya?

\begin{tabular}{|l|l|l|l|l|l|}
\hline No. & Option & $\begin{array}{l}\text { Frekuensi } \\
(\mathrm{F})\end{array}$ & $\begin{array}{l}\text { Hasil } \\
\text { persentase } \\
\text { (P) }\end{array}$ & $\begin{array}{l}\text { Hasil } \\
\text { akumulatif } \\
\text { Persentase } \\
\text { (AP) }\end{array}$ & Keterangan \\
\hline 1 & A & 1 & $12,5 \%$ & $75 \%$ & $\begin{array}{l}\text { Dari data ini dapat dilihat } \\
\text { bahwa sumber data akan } \\
\text { pemimpin yang mampu } \\
\text { menerima setiap pribadi } \\
\text { orang yang dipimpinnya } \\
\text { adalah sangat menerap-kan. }\end{array}$ \\
\hline
\end{tabular}


Hasil rata-rata akumulatif persentase tentang profil Daud sebagai pemimpin adalah sebagai berikut:

\begin{tabular}{|c|c|c|c|c|c|}
\hline No. & $\begin{array}{l}\text { Aspek yang } \\
\text { dipertanyakan }\end{array}$ & $\begin{array}{l}\text { Presentase } \\
\text { (P) }\end{array}$ & $\begin{array}{l}\text { Jumlah hasil } \\
\text { Seluruh } \\
\text { presentase }\end{array}$ & $\begin{array}{l}\text { Akumu- } \\
\text { latif } \\
\text { presen-tase } \\
\text { (AP) }\end{array}$ & Keterangan \\
\hline 1 & $\begin{array}{l}\text { Pemimpin yang } \\
\text { menerapkan } \\
\text { komunikasi yang } \\
\text { baik. }\end{array}$ & $78,125 \%$ & \multirow{8}{*}{$581,25 \%$} & \multirow{8}{*}{$72,65625 \%$} & \multirow{8}{*}{$\begin{array}{l}\text { Dari deskriptif yang } \\
\text { ditampilkan data, dapat dilihat } \\
\text { dengan jelas bahwa warga } \\
\text { Gereja Orthodox Evangelismos } \\
\text { Pargambir-an menerapkan } \\
\text { kepemim-pinan Daud di Gereja } \\
\text { Orthodox Evangelismos } \\
\text { Pargambiran. Ini terbukti dari } \\
\text { hasil presentase sebesar } \\
\text { 72,65622\% yang menyatakan } \\
\text { kepemim-pinan Daud dalam } \\
\text { memimpin seluruh jemaat } \\
\text { mereka. }\end{array}$} \\
\hline 2 & $\begin{array}{l}\text { Pemimpin yang } \\
\text { selalu berusaha } \\
\text { melakukan yang } \\
\text { terbaik dihadapan } \\
\text { Tuhan. }\end{array}$ & $68,75 \%$ & & & \\
\hline 3 & $\begin{array}{l}\text { Pemimpin yang } \\
\text { mampu } \\
\text { menyadari siap } \\
\text { dirinya dihadapan } \\
\text { Tuhan. }\end{array}$ & $75 \%$ & & & \\
\hline 4 & $\begin{array}{l}\text { Pemimpin yang } \\
\text { rendah hati dan } \\
\text { pemberani }\end{array}$ & $71,875 \%$ & & & \\
\hline 5 & $\begin{array}{l}\text { Pemimpin yang } \\
\text { memiliki hikmat } \\
\text { yang berasal dari } \\
\text { Allah }\end{array}$ & $68,75 \%$ & & & \\
\hline 6 & $\begin{array}{l}\text { Pemimpin yang } \\
\text { mengandalkan } \\
\text { Tuhan dalam } \\
\text { segala hal } \\
\text { kepemimpinan }\end{array}$ & $71,875 \%$ & & & \\
\hline 7 & $\begin{array}{l}\text { Pemimpin yang } \\
\text { mampu } \\
\text { menempatkan diri } \\
\text { sebagai pemimpin }\end{array}$ & $71,875 \%$ & & & \\
\hline 8 & $\begin{array}{l}\text { Pemimpin yang } \\
\text { mampu menerima } \\
\text { setiap pribadi } \\
\text { orang yang } \\
\text { dipimpinnya }\end{array}$ & $75 \%$ & & & \\
\hline
\end{tabular}

\section{Analisis Data}

Dari data yang telah terlampir, hasilnya menunjukkan bahwa respon sumber data terhadap Profil Daud sebagai pemimpin adalah baik karena mereka menerapkan kepemimpinan Daud dalam memimpin seluruh jemaat yang ada di Gereja Orthodox Evangelismos Pargambiran, Sumbul. Hal ini terbukti dari pilihan jawabannya terhadap pertanyanpertanyaan adalah menerapkan, denga pemaparan sebagai berikut:

Pertama, pemimpin yang menerapkan komunikasi yang baik yaitu yang memilih sangat menerapkan adalah 25\%, menerapkan 62,5\%, kurang menerapkan 12,5\%, yang tidak menerapkan o\%. Hasil akumulatif presentase $78,125 \%$ artinya bahwa respon pemimpin jemaat terhadap pemimpin yang menerapkan komunikasi yang baik adalah mereka sangat menerapkan. 
Kedua, pemimpin yang selalu berusaha melakukan yang terbaik dihadapan Tuhan, yang memilih sangat menerapkan adalah $12,5 \%$, menerapkan $50 \%$, kurang menerapkan $37,5 \%$, tidak menerapkan $0 \%$. Hasil akumulatif presentase adalah $68,75 \%$, yang menunjukkan bahwa respon pemimpin jemaat terhadap pemimpin yang selalu berusaha melakukan yang terbaik dihadapan Tuhan adalah menerapkan.

Ketiga, pemimpin yang mampu menyadari siapa dirinya dihadapan Tuhan, yang memilih sangat menerapkan $12,5 \%$, menerapkan $75 \%$, kurang menerapkan $12,5 \%$, tidak menerapkan $0 \%$. Hasil akumulatif presentase adalah $75 \%$, artinya bahwa respon pemimpin jemaat yang mampu menyadari siapa dirinya di hadapan Tuhan adalah sangat menerapkan.

Keempat, pemimpin yang rendah hati dan pemberani, yang memilih sangat menerapkan $25 \%$, menerapkan 37,5\%, kurang menerapkan 37,5\%, tidak menerapkan $0 \%$. Hasil akumuatif presentase sebesar $71,875 \%$ menunjukkan bahwa respon pemimpin jemaat yang rendah hati dan pemberani adalah menerapkan.

Kelima, pemimpin yang memiliki hikmat yang berasal dari Allah, yang menili sangat menerapkan 12,5\%, menerapkan 50\%, kurang menerapkan 37,5\%, tidak menerapkan $0 \%$. Hasil akumulatif presentase adalah $68,75 \%$ menunjukkan bahwa respon pemimpin jemaat yang menerapkan kerendahan hati dan berani dalam memimpin jemaat adalah menerapkan.

Keenam, pemimpin yang mengandalkan Tuhan dalam segala hal kepemimpinan, yang memilih sangat menerapkan $12,5 \%$, menerapkan $62,5 \%$, kurang menerapkan $25 \%$, tidak menerapkan $0 \%$. Hasil akumulatif presentase sebesar $71,875 \%$ artinya bahwa respon oemimpin yang mengandalkan Tuhan dalam segala hal kepemimpinan meraka adalah menerapkan.

Ketujuh, pemimpin yang mampu menempatkan diri sebagai pemimpin, yang memilih sangat menerapkan 12,5\%, menerapkan $62,5 \%$, kurang menerapkan $25 \%$, tidak menerapkan $0 \%$. Hasil akumulatif presentase sebesar $71,875 \%$ menunjukkan bahwa pemimpin yang menempatkan dirinya sebagai pemimpin dalam memimpin jemaat adalah menerapkan.

Kedelapan, pemimpin yang mampu menerima setiap pribadi orang yang dipimpinnya, yang memilih sangat menerapkan $12,5 \%$, menerapkan $75 \%$, kurang menerapkan 12,5\%, tidak menerapkan 0\%. Hasil akumulatif presentase sebesar $75 \%$ menunjukkan bahwa pemimpin yang mampu menerima setiap pribadi jemaat yang dipimpinnya adalah sangat menerapkan.

Hasil perhitungan akumulatif presentase $72,65625 \%$, hal ini membuktikan bahwa pemimpin jemaat Gereja Orthodox Evangelismos Pargambiran Sumbul benar menerapkan kepamimpinan Daud dalam memimpin jemaat mereka. Ini menunjukkan bahwa pemimpin jemaat Gereja Orthodox Evangelismos Pargambiran benar memahami profil Daud sebagai pemimpin, yaitu orang yang benar-benar dipilih oleh Allah dan memiliki skil yang baik serta memiliki kerendahan hati dalam memimpin warga jemaat.

Melalui hasil analisis data, ditemukan bahwa yang menerapkan kepemimpinan Daud dalam memimpin jemaat memiliki respon yang sangat baik dengan presentase $72,65625 \%$ dari pemimpin jemaat Gereja Orthodox Evangelismos Pargambiran, Sumbul. Pengaruhnya 
telah membawa hal yang positif bagi kehidupan dan keseharian pemimpin jemaat dalam memimpin warga jemaat mereka.

Pemimpin jemaat Gereja Orthodox Evangelismos Pargambiran juga cukup mengerti bagaimana kepemimpinan Daud dalam memimpin bangsa Israel dan juga dalam kepemimpinannya dalam menggembalakan domba-dombanya dalam hal memimpin jemaat mereka sesuai dengan kepemimpinan Daud yang mereka mengerti walaupun tidak maksimal 100\%. Namun dapat dilihat secara jelas bahwa pemimpin jemaat gereja Gereja Orthodox Evangelismos Pargambiran sudah menerapkan kepemimpinan Daud dalam kepemimpinan mereka di dalam memimpin jemaat mereka. Dengan mempraktekkan temuan ini, maka diharapkan kepemimpinan Gereja Orthodox Evangelismos Pargambiran akan bertumbuh ke arah yang lebih baik.

\section{KESIMPULAN}

Kesimpulan dalam penelitian ini adalah: Pertama, pemimpin Gereja Orthodox Evangelismos Pargambiran sedang mengakui bahwa kepemimpinan itu berasal dari Allah sendiri. Karena itulah mereka harus bersikap rendah hati dan tulus hati. Kedua, pemimpin Gereja Orthodox Evangelismos Pargambiran adalah orang-orang yang sudah mengetahui faktor yang mempengaruhi keberhasilan pemimpin berdasarkan profil Daud.

\section{REFERENSI}

Alkitab. Jakarta: Lembaga Alkitab Indonesia, 2020

Archer, Jules. Kisah Para Diktator. Jakarta: Narasi, 2004.

C. Maxwel, John. Mengembangkan Kepemimpinan di Dalam Diri Anda. Georgia: Equip, Injoy, Inc, 1993.

Fredsmith, SR. Pemimpin Dengan Integritas. Jakarta: Immanuel, 2000.

Harefa, Etiknius. Diktat Metode Penelitian Theologia. Medan: STT Paulus, 2011.

Iamy, Soejona. Analisis Kepemimpinan. Bandung: Angkasa, 1989.

Kenneth dan Linda Schatz. Keberhasilan Daya Dalam Pengaruh Manajemen. Jakarta:

Spectrum Mitra Utama, 1995.

MacAtur, John. Kitab Kepemimpinan. Jakarta: Erlangga, 1983.

Moleong, Lexy. Metode Penelitian Kualitatif. Bandung: PT. Remaja Rosdakarya, 1989.

R. Swindoll, Charles. Kepemimpinan Kristen Yang Berhasil. Surabaya: Yakin, 2003

Samarenna, Desti, and Harls Evan R Siahaan. "Memahami Dan Menerapkan Prinsip

Kepemimpinan Orang Muda Menurut 1 Timotius 4:12 Bagi Mahasiswa Teologi."

BIA': Jurnal Teologi dan Pendidikan Kristen Kontekstual 2, no. 1 (2019): 1-13.

http://www.jurnalbia.com/index.php/bia.

Sanders, J. Oswald. Spiritual Leadership. Chicago: Moody, 1967.

Sudjana, Nana. Penelitian dan Penilaian Pendidikan. Jakarta: Sinar Baru Algensindo, 2001

S, Nasution. Penunutun Membuat Disertasi Tesis, Paper. Bandung: Jammer, 1990.

Willy, Jonathan. Lead by Heart. Yogyakarta: Andi Offset, 2009.

Yacob Tomatala, Kepemimpinan Yang Dinamis. Jakarta: YT Leadership Foundation, 1997.

Zuck, Roy B. Teologi Alkitabiah Perjanjian Lama. Malang: Gandum Mas, 2005. 